African Crop Science Journal by African Crop Science Society is licensed under a Creative Commons Attribution 3.0 Uganda License. Based on a work at www.ajol.info/ and www.bioline.org.br/cs DOI: https://dx.doi.org/10.4314/acsj.v27i2.11

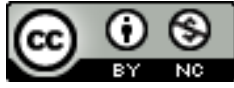

\title{
ADAPTATION AND STABILITY OF VEGETABLE SOYBEAN GENOTYPES IN UGANDA
}

\author{
A. TSINDI, R. KAWUKI ${ }^{1}$ and P. TUKAMUHABWA \\ College of Agricultural and Environmental Sciences, Department of Agricultural Production, \\ Makerere University, P. O. Box 7062, Kampala, Uganda \\ ${ }^{1}$ National Crops Resources Research Institute, Namulonge, P. O. Box 7084, Kampala, Uganda \\ Corresponding author: tsindialb@gmail.com
}

(Received 30 April 2018.; accepted 15 May 2019)

\begin{abstract}
Vegetable soybean (Glycine max L. Merr.) is a specialty soybean, harvested as a vegetable when seeds are immature (R6 stage) and have expanded to fill 80 to $90 \%$ of the pod. The objective of the study was to assess the adaptation and stability of vegetable soybean genotypes in different agroecological zones of Uganda to enable selection of genotypes. A total of 21 genotypes were planted in Uganda for two consecutive seasons. Genotypes PI615437-B had the highest number of pods, while AGS 329 matured earliest in 64 days. Only AGS 292, AGS 329 and AGS 338 had 100 seeds weight above $30 \mathrm{~g}$. G10427 was the ideal genotype in terms of adaptation and stability for fresh seed yield, with mean yield of $4281 \mathrm{~kg} \mathrm{ha}^{-1}$; followed by G2843 with $4039 \mathrm{~kg} \mathrm{ha}^{-1}$. PI615437-B came third with fresh seed yield of $4024 \mathrm{~kg} \mathrm{ha}^{-1}$. The least stable and adapted genotype was AGS 329 with only $1609 \mathrm{~kg} \mathrm{ha}^{-1}$. Nakabango 1 and MUARIK 1 were the ideal environments, which were the most discriminative and representative. We recommend that $\mathrm{G} 10427$ be used as a test genotype and for improvement to produce a variety with good attributes, especially large seed, high yield and adaptable to Uganda.
\end{abstract}

Key Words: Discriminative, Glycine max, specialty bean

\section{RÉSUMÉ}

Le soja (Glycine max L. Merr.) Est un soja de spécialité, récolté comme légume quand les graines sont immatures (stade R6) et s'est développé pour remplir 80 à $90 \%$ de la gousse. L'objectif de l'étude était d'évaluer l'adaptation et la stabilité des génotypes de soja végétal dans différentes zones agroécologiques de l'Ouganda pour permettre la sélection des génotypes. Au total, 21 génotypes ont été plantés en Ouganda pendant deux saisons consécutives. Les génotypes PI615437-B avaient le plus grand nombre de gousses, tandis qu'AGS 329 est arrivé à maturité plus tôt en 64 jours. Seulement AGS 292, AGS 329 et AGS 338 avaient un poids de 100 graines supérieur à 30 g. G10427 était le génotype idéal en termes d'adaptation et de stabilité pour le rendement en semences fraîches, avec un rendement moyen de $4281 \mathrm{~kg} \mathrm{ha}^{-1}$; suivi de G2843 avec $4039 \mathrm{~kg} \mathrm{ha}^{-1}$. Le PI615437-B est arrivé troisième avec un rendement en graines fraîches de $4024 \mathrm{~kg} \mathrm{ha}^{-1}$. Le génotype le moins stable et le plus adapté était AGS 
329 avec seulement $1609 \mathrm{~kg} \mathrm{ha}^{-1}$. Nakabango 1 et MUARIK 1 étaient les environnements idéaux, les plus discriminants et les plus représentatifs. Nous recommandons que G10427 soit utilisé comme génotype de test et pour l'amélioration afin de produire une variété en particulier des graines de grande taille, à haut rendement et adaptable à l'Ouganda.

Mots Clés: sélectif, Glycine max, spécialité du haricot

\section{INTRODUCTION}

Vegetable soybean (Glycine $\max$ (L.) Merr.) is a specialty soybean, harvested as a vegetable when the seed is immature (R6 stage) and is expanded to fill 80 to $90 \%$ of the pod width (Konovsky et al., 1994). Although soybean is said to have originated from China, the earliest reliable evidence of consumption of vegetable soybean (edamame) dates from $1275 \mathrm{AD}$ in Japan (Shurtleff and Aoyagi, 2009). Edamame is consumed mainly as a snack, but also as a vegetable, in addition to soups; or processed into sweets. As a snack, the pods are slightly cooked in salted boiling water, and then the seeds are pushed directly from the pods into the mouth. As a vegetable, the beans are mixed with salads, stir-fried or combined with mixed vegetables (Mentreddy et al., 2002).

The fresh vegetable soybean seed can provide 35 to $38 \%$ protein and 5 to $7 \%$ lipid on fresh weight basis; and is one of the few natural sources of isoflavones (Mentreddy et al., 2002). Isoflavones are important nutraceuticals (Hartman et al., 2011), for human health, which help to prevent the buildup of arterial plaques, reduce breast cancer by blocking the cancer-causing effects of human estrogen, prevent prostate cancer by hindering cell growth, fight osteoporosis by stimulating bone formation and inhibiting bone resorption (Bolla, 2015). Other health benefits include, decreasing low density lipoprotein (LDL) cholesterol levels and reducing the risk of cardiovascular diseases. The benefits have made the demand for vegetable soybean to increase throughout the world (Duppong and Hatterman-valenti, 2005). Despite the fact that vegetable soybean fulfils dietary protein requirements, its production still remains low in Africa where malnutrition is widespread due to low production, which is essentially caused by lack of well adapted varieties (Mebrahtu and Devine, 2009).

Uganda is one of the leading soybean producers in Africa (Tukamuhabwa and Oloka, 2016), but very little effort has been made to develop and promote vegetable soybean cultivars. Burker (2001) introduced a vegetable soybean variety AGS 292 to Uganda. This variety was tasted as vegetable in Serena Hotel (Shurtleff and Aoyagi, 2009), but no efforts were made to grow it. Chadha and Oluoch (2004) also reported that between 1998 and 2003, Uganda received 28 vegetable soybean lines from Taiwan - AVRDC. However, according to the national soybean programme, these genotypes have not been evaluated in different locations in Uganda to determine their performance in major soybean producing areas.

For these genotypes to be grown commercially by farmers in Uganda, there is need to evaluate the genotypes in different environments to ascertain their performance that is to assess genotypes by environment interaction $(\mathrm{GxE})$. The presence of $\mathrm{GxE}$ interactions can hinder progress from selection by masking genotypic effects (Mebrahtu et al., 1991). Genotype by environmental interaction (GxE) governs the identification of stable genotypes that are suitable for some particular environments (Mustapha and Bakari, 2014), as well as of genotypes with a general performance that are suitable for several environments (Mohamed, 2013), which can then be released for production by farmers or developed further. The objective of the study was to assess the adaptation and stability of vegetable soybean 
genotypes in different agro-ecological zones of Uganda to enable selection of genotypes.

\section{MATERIALS AND METHODS}

Experimental sites. This research was carried out in six sites, in major soybeans producing areas of Uganda; namely, Makerere University Agricultural Research Institute Kabanyolo (MUARIK), National Crops Resources and Research Institute - NaCRRI (Namulonge), Jinja (Nakabango), Budaka (IkiIki), Lira (Ngetta) and Kasese (Mubuku). The geographical description of the areas is summarised in Table 1.

Treatment and design. A total of 21 soybean genotypes were planted in a randomised complete block design (RCBD), with 2 replications in each of the six locations. Each entry was represented by two rows, each measuring $2 \mathrm{~m}$; with $0.05 \mathrm{~m}$ in-row and 0.6 $\mathrm{m}$ inter row spacing. The study was conducted for two consecutive rainy seasons; the first and second seasons of 2014. Thus, the GXE analysis was based on 12 testing environments. Standard agronomic practices for weeding and pest control were applied (Kokobun, 1991).

Data collection. The following traits were recorded according to the International Descriptors for Soybean by International Board for Plant Genetic Resources (IBPGR, 1984); plant height, days to $50 \%$ flowering, number of pods per plant, days to harvest/ maturity. Data was also recorded on fresh seed yield. A total of 100 seeds were weighed using a CenTech ${ }^{\circledR}$ digital scale. The absolute values in grammes for the weight of each genotype were recorded.

At pod filling stage (R6 stage), all pods were harvested by hand picking. Total pods weight was taken per plot for each genotype at all the locations, using a Cen-Tech ${ }^{\circledR}$ digital scale. The pods were shelled and the fresh seed weight per plot was recorded and extrapolated into kilogrammes per hectare using the following conversion formula:

Fresh seed yield $\left(\mathrm{kg} \mathrm{ha}^{-1}\right)=$

The yield obtained per plot $(\mathrm{kg})$

$$
\frac{\text { Plot size }\left(\mathrm{m}^{2}\right)}{2} \times 10000
$$

Data analysis. All data collected were evaluated using Analysis of variance in GenStat version 13. Significant means were separated using Fishers Least Significant Difference, at $\mathrm{P}<0.05$.

AMMI analysis was performed for fresh seed yield to determine the contribution of each component (genotype, environment and genotype by environment interaction) to the total variation. AMMI biplots were generated for fresh seed yield to display the genotypic

TABLE 1. Characteristics of experimental sites used for the evaluation of vegetable soybean in Uganda

\begin{tabular}{lllccc}
\hline Location & Position & $\begin{array}{l}\text { Location } \\
\text { in Uganda }\end{array}$ & $\begin{array}{c}\text { Altitude } \\
(\mathrm{m} . \text { a.s.l })\end{array}$ & $\begin{array}{c}\text { Mean annual } \\
\text { temperature }\left({ }^{\circ} \mathrm{C}\right)\end{array}$ & $\begin{array}{c}\text { Mean annual } \\
\text { rainfall }(\mathrm{mm})\end{array}$ \\
\hline Namulonge & $0^{\circ} 32^{1} \mathrm{~N} / 32^{\circ} 37^{1} \mathrm{E}$ & Central & 1.160 & 22.6 & 1,400 \\
Nakabango & $0^{\circ} 2^{1} \mathrm{~N} / 33^{\circ} 14^{1} \mathrm{E}$ & Eastern & 1.210 & 22.8 & 1,400 \\
Iki-Iki & $1^{\circ} 06^{1} \mathrm{~N} / 34^{\circ} 00^{1} \mathrm{E}$ & Eastern & 1.156 & 24.7 & 1,200 \\
Ngetta & $2^{\circ} 17^{1} \mathrm{~N} / 32^{\circ} 56^{1} \mathrm{E}$ & Northern & 1.103 & 24.7 & 1,200 \\
Mubuku & $0^{\circ} 13^{1} \mathrm{~N} / 30^{\circ} 08^{1} \mathrm{E}$ & Western & 1.007 & 27.8 & 750 \\
MUARIK & $0^{\circ} 27^{\prime} \mathrm{N} / 32^{\circ} 36^{\prime} \mathrm{E}$ & Central & 1.170 & 21.5 & 1150 \\
\hline
\end{tabular}

Source: Meteorological stations at the study sites; m.a.s.l = meters above sea level 
stability and yielding ability. GGE biplots were used to determine the mega environments and to display the "which won were" pattern of the genotypes in the 12 environments. GGE Comparison biplots were plotted to determine the ideal genotype and environment.

\section{RESULTS}

Plant height. There were significant differences $(\mathrm{P}<0.001)$ in plant height among the 21 genotypes (Table 2). Genotypes PI615437-B and PI606405 had the tallest plants. However, they were grouped together with the other nine genotypes (AGS 338, SRE-
B-15, G10427, GC 85037-2-3-54, G8527, PI628919, PI628908, SERENADE and GC 84051-31-1) as tall plants, since they were more than $45 \mathrm{~cm}$ tall. Nine genotypes (AGS 292, AGS 329, KUNTZ, G548360, G2843, PI615437, K-LOCAL, SRED-11-13 and G50) had heights ranging from $30.7 \mathrm{~cm}$ for AGS 292 being the shortest to $51.7 \mathrm{~cm}$ for PI615437 (Table 2). Only G78 had dwarf plants with average height of $24.5 \mathrm{~cm}$ and was also significantly different from all other genotypes.

Days to $50 \%$ flowering. There were significant differences $(\mathrm{P}<0.001)$ among the genotypes in number of days to $50 \%$ flowering

TABLE 2. Characteristics of genotypes used in the vegetable soybean study of in Uganda

\begin{tabular}{|c|c|c|c|c|c|c|}
\hline Genotype & $\begin{array}{l}\text { Source } \\
\text { (Origin) }\end{array}$ & $\begin{array}{l}\text { Mean plant } \\
\text { height }(\mathrm{cm})\end{array}$ & $\begin{array}{c}\text { Days to } 50 \% \\
\text { flowering }\end{array}$ & $\begin{array}{l}\text { Average } \\
\text { number } \\
\text { of pods } \\
\text { per plant }\end{array}$ & $\begin{array}{l}\text { Average } \\
\text { number } \\
\text { of days to } \\
\text { maturity }\end{array}$ & $\begin{array}{l}\text { 100-seed } \\
\text { fresh } \\
\text { weight } \\
\text { (g) }\end{array}$ \\
\hline AGS 292 & AVRDC & 30.7 & 30 & 11 & 83 & 30.5 \\
\hline AGS 329 & AVRDC & 40.3 & 30 & 10 & 64 & 33 \\
\hline KUNTZ & USA & 39.2 & 30 & 16 & 79 & 19.5 \\
\hline AGS 338 & AVRDC & 54.6 & 34 & 13 & 79 & 30.5 \\
\hline SRE-B-15 & AVRDC & 45.8 & 30 & 13 & 97 & 25.5 \\
\hline G10427 & AVRDC & 49.7 & 35 & 15 & 77 & 24.5 \\
\hline G548360 & AVRDC & 38.3 & 30 & 12 & 81 & 28.5 \\
\hline PI615437B & USA & 80.9 & 44 & 31 & 70 & 21.5 \\
\hline G2843 & AVRDC & 42.5 & 31 & 22 & 87 & 25.5 \\
\hline G78 & USA & 24.5 & 28 & 20 & 70 & 27.5 \\
\hline PI615437 & USA & 51.7 & 39 & 23 & 88 & 20 \\
\hline K-LOCAL & Unknown & 46.4 & 27 & 21 & 86 & 20 \\
\hline GC 85037-2-3-54 & AVRDC & 53.9 & 34 & 20 & 96 & 16 \\
\hline G8527 & AVRDC & 49.8 & 31 & 30 & 75 & 15.5 \\
\hline PI606405 & USA & 82 & 43 & 18 & 77 & 15.5 \\
\hline PI628919 & USA & 55.9 & 45 & 23 & 106 & 24 \\
\hline SRED-11-13 & AVRDC & 42.5 & 31 & 17 & 80 & 20.5 \\
\hline PI628908 & USA & 63.5 & 44 & 23 & 82 & 13 \\
\hline SERENADE & USA & 57.4 & 39 & 23 & 97 & 18.5 \\
\hline GC 84051-31-1 & AVRDC & 55.5 & 34 & 10 & 88 & 21 \\
\hline G50 & USA & 40.4 & 32 & 14 & 76 & 27.5 \\
\hline L.S.D(0.05) & & 8.26 & 5.57 & 9.13 & 15.58 & 2.78 \\
\hline C.V(\%) & & 8 & 7.8 & 24.7 & 9 & 5.9 \\
\hline
\end{tabular}

AVRDC $=$ Asian Vegetable Research and Development Center; USA= United States of America 
(Table 2). Genotype PI628919 had the longest period (45 days), although it was not significantly different from PI615437-B, PI606405 and PI628908, which took 44, 43 and 44 days to reach $50 \%$ flowering, respectively. On the other hand, K-LOCAL had the shortest period to $50 \%$ flowering (27 days). However, this was not significantly different from genotypes AGS 292, AGS 329, KUNTZ, SRE-B-15, G548360, G2843, G78, G8527, SRED-11-13 and G50 all of which had their 50\% flowering time ranging from 28 to 32 days. Most of the genotypes were classified as early flowering because they had less than 36 days to reach $50 \%$ flowering. Only six genotypes (PI615437-B, PI615437, PI606405, PI628919, PI628908 and SERENADE) were classified as medium flowering, having days ranging between 36 and 45 to reach $50 \%$ flowering. No genotype was classified as late flowering.

Maturity. There were significant differences $(\mathrm{P}<0.001)$ among genotypes for number of days to maturity (Table 2). The number of days to maturity ranged from 64 to 106 . AGS 329 matured earlier than all other genotypes, with days to maturity of 64. PI628919 had the longest maturity period of 106 days; followed by SRE-B-15 and SERENADE both having the same number of days to maturity of 97 .

Pod number. Significant differences $(\mathrm{p}<0.001)$ among genotypes for pod number were also observed (Table 2). Genotypes PI615437-B and G8527 had the highest number of pods per plant (31 and 30 pods per plant, respectively). These were the only genotypes which qualified to be classified as having medium number of pods per plant. AGS 329 and GC 84051-31-1 had the least number of pods both having 10 pods per plant, which were also not significantly different from AGS 292, KUNTZ, AGS 338, SRE-B-15, G10427, G548360, G78, GC 85037-2-3-54, PI606405, SRED-11-13 and G50. Genotypes PI615437 PI628919, PI628908 and SERENADE produced similar pods per plant of 23; and were not significantly different from the genotypes KUNTZ, G10427, G2843, G78, PI615437, K-LOCAL, GC 85037-2-3-54, PI606405, PI628919, SRED-11-13, PI628908, SERENADE and G50; which bore pods ranging from 14 to 21 per plant.

100 seed weight and total yield. There were significant differences among genotypes $(\mathrm{P}<0.05)$ for 100 -seed weight (Table 2$)$; ranging from 13 to $33 \mathrm{~g}$. Only three genotypes AGS 292, AGS 329 and AGS 338 had a 100 seeds weight above $30 \mathrm{~g}$. PI628908 had the least weight of $13 \mathrm{~g}$.

There were significant differences $(\mathrm{P}<0.05)$ for fresh seed yield among genotypes and environments (Table 3). Ngetta, Namulonge and Iki Iki had higher seed yield in the first season than in the second season; while MUARIK, Mubuku and Nakabango had higher yield in the second growing season of 2014. Overall, the highest performing genotypes for fresh seed yield were G10427 with $4,281 \mathrm{~kg} \mathrm{ha}^{-1}$ and G2843 with $4039 \mathrm{~kg}$ $\mathrm{ha}^{-1}$; while the least performing genotype was AGS 329 with only $1609 \mathrm{~kg} \mathrm{ha}^{-1}$ (Table 3).

AMMI analysis. AMMI analysis showed that environment, genotype and genotype $\mathrm{x}$ environment interaction (GXE) components were all significant $(\mathrm{P}<0.001)$ (Table 4$)$. The environment had the highest contribution $(63.28 \%)$ to the total variation, GXE had a contribution of $27.74 \%$, and genotype had the least contribution (8.97\%) to the total variation. The first two Interaction Principal Component Axis (IPCA) captured $52.97 \%$ of the variation with IPCA1 capturing $36.26 \%$ and IPCA2 capturing $16.71 \%$ (Table 4).

The AMMI Biplot for fresh seed yield showed that genotypes AGS 329, AGS 292, G50, G548360 and G8527 were low yielding and unstable (Fig. 1). High yielding and moderately stable genotypes included $\mathrm{K}$ LOCAL, PI628919, SRE-B-15C and GC85037-2-3-54. Genotypes GC 81051-31-1, 
TABLE 3. Yield $\left(\mathrm{kg} \mathrm{ha}^{-1}\right)$ of 21 vegetables soybeans evaluated at 12 testing environments in Uganda

\begin{tabular}{|c|c|c|c|c|c|c|c|c|c|c|c|c|c|}
\hline \multirow[t]{2}{*}{ Genotype } & \multicolumn{2}{|c|}{ MUARIK } & \multicolumn{2}{|c|}{ Namulonge } & \multicolumn{2}{|c|}{ Ngetta } & \multicolumn{2}{|c|}{ Iki Iki } & \multicolumn{2}{|c|}{ Mubuku } & \multicolumn{2}{|c|}{ Nakabango } & \multirow[t]{2}{*}{ Means } \\
\hline & $2014 \mathrm{~A}$ & 2014B & $2014 \mathrm{~A}$ & 2014B & $2014 \mathrm{~A}$ & 2014B & $2014 \mathrm{~A}$ & 2014B & $2014 \mathrm{~A}$ & 2014B & 2014A & 2014B & \\
\hline AGS 292 & 3883 & 7700 & 1992 & 692 & 3458 & 3042 & 304 & 363 & 250 & 4233 & 2267 & 2696 & 2573 \\
\hline AGS 329 & 4183 & 6346 & 1729 & 858 & 313 & 538 & 400 & 8 & 1912 & 1937 & 208 & 871 & 1609 \\
\hline AGS 338 & 2733 & 9929 & 1275 & 925 & 5263 & 3283 & 1904 & 142 & 2146 & 4892 & 771 & 5775 & 3253 \\
\hline G10427 & 5896 & 6621 & 2037 & 8513 & 6250 & 2829 & 4433 & 342 & 2142 & 3704 & 5154 & 3446 & 4281 \\
\hline G2843 & 6008 & 9408 & 2188 & 1554 & 2758 & 3300 & 2883 & 50 & 6442 & 6521 & 4217 & 3142 & 4039 \\
\hline G50 & 3204 & 6213 & 1212 & 1238 & 1446 & 1842 & 2212 & 229 & 2125 & 3896 & 913 & 2379 & 2242 \\
\hline G548360 & 779 & 6225 & 2075 & 383 & 3471 & 2054 & 1179 & 158 & 2046 & 3533 & 975 & 3888 & 2231 \\
\hline G78 & 3629 & 9017 & 2113 & 1408 & 2313 & 2471 & 1258 & 67 & 2387 & 3558 & 1521 & 3304 & 2754 \\
\hline G8527 & 2713 & 8662 & 2067 & 662 & 2825 & 1225 & 1271 & 79 & 1413 & 3562 & 363 & 2833 & 2306 \\
\hline GC 84051-31-1 & 5342 & 5175 & 3542 & 1233 & 8888 & 2921 & 5142 & 117 & 3258 & 2329 & 863 & 2688 & 3458 \\
\hline GC-85037-2-3-54 & 5792 & 7917 & 3833 & 2775 & 5308 & 1842 & 1967 & 225 & 2417 & 3171 & 3442 & 2575 & 3439 \\
\hline K-LOCAL & 6133 & 8754 & 3271 & 2000 & 3175 & 3275 & 3233 & 317 & 1737 & 2308 & 2413 & 4067 & 3390 \\
\hline KUNTZ & 3963 & 8171 & 2854 & 1721 & 3092 & 3192 & 912 & 54 & 3158 & 5517 & 896 & 2329 & 2988 \\
\hline PI606405 & 6296 & 6346 & 4283 & 1325 & 6013 & 1450 & 3208 & 96 & 5517 & 5238 & 3446 & 2808 & 3835 \\
\hline PI615437 & 6246 & 6792 & 3958 & 1971 & 5700 & 1617 & 4792 & 271 & 2617 & 2492 & 3533 & 2508 & 3541 \\
\hline PI615437-B & 6304 & 9146 & 3779 & 1071 & 7933 & 1688 & 4117 & 58 & 3133 & 4021 & 3488 & 3546 & 4024 \\
\hline PI628908 & 5133 & 7450 & 2263 & 1117 & 6329 & 1475 & 4333 & 267 & 3308 & 5296 & 3529 & 2479 & 3582 \\
\hline PI628919 & 1692 & 8650 & 2992 & 1992 & 5233 & 2125 & 3408 & 204 & 2837 & 5383 & 3633 & 1917 & 3339 \\
\hline SERENADE & 7263 & 9129 & 2708 & 2383 & 8446 & 1087 & 3525 & 75 & 2275 & 2675 & 1887 & 1629 & 3590 \\
\hline SRE - B-15C & 4763 & 6446 & 2671 & 2004 & 5125 & 1192 & 2967 & 258 & 2233 & 4012 & 3846 & 3554 & 3256 \\
\hline SRED-11-13 & 3513 & 6217 & 1850 & 1375 & 2838 & 2167 & 2442 & 575 & 2392 & 5008 & 2629 & 5429 & 3036 \\
\hline $\operatorname{LSD}(0.05)$ & 2318.8 & 2167.1 & 1519.4 & 3910.5 & 3015.9 & 1739.4 & 1926.4 & 262.1 & 2617.2 & 2338.7 & 2594.6 & 1047.5 & 1314.7 \\
\hline
\end{tabular}

Each location in one season constitute an environment 
TABLE 4. AMMI analysis of variance for fresh seed weight for the 21 vegetable soybean genotypes evaluated at 12 environments in Uganda

\begin{tabular}{lrrrrr}
\hline Source & Df & \multicolumn{1}{c}{ SS } & MS & F & F_prob \\
\hline Total & 503 & 2874321653 & 5714357 & & \\
Treatments & 251 & 2512941375 & 10011719 & 8.20 & 0.00 \\
Genotypes & 20 & 225502770 & 11275138 & 9.24 & 0.00 \\
Environments & 11 & 1590292456 & 144572041 & 25.33 & 0.00 \\
Block & 12 & 68485347 & 5707112 & 4.68 & 0.00 \\
Interactions & 220 & 697146149 & 3168846 & 2.60 & 0.00 \\
IPCA 1 & 30 & 252773882 & 8425796 & 6.90 & 0.00 \\
IPCA2 & 28 & 116504431 & 4160873 & 3.41 & 0.00 \\
IPCA3 & 26 & 93443368 & 3593976 & 2.94 & 0.00 \\
Residuals & 136 & 234424468 & 1723709 & 1.41 & 0.01 \\
Error & 240 & 292894931 & 1220396 & & \\
\hline
\end{tabular}

SERENADE, PI61543, AGS 338 and G2843 were high yielding, but environmentally unstable. Environments MUARIK 2 (E7), MUARIK 1 (E1) and Ngetta 1 (E3) were high yielding, but unstable for fresh seed yield. On the other hand, Namulonge 1 (E2), Nakabango 1 (E6), Namulonge 2 (E8) and Mubuku 1 (E5) were low yielding but stable; while Nakabango 2 (E12), Ngetta 2 (E9), Iki Iki 1 (E4) were low yielding and unstable environments.

GGE Biplots for mega-environment. The scatter plot for the fresh seed yield demarcated three mega environments (Fig. 2). The first mega environment comprised of Iki Iki 2, MUARIK 2, Ngetta 2, Mubuku 1, Mubuku 2, Nakabango 1; and Nakabango 2. The best performing cultivar was G2843, and other genotypes that performed well in this first mega environment were PI628919, AGS 338, KUNTZ and SRED-11-13. The second mega environment had MUARIK 1, Iki Iki 1 and Namulonge 2 with a best cultivar G10427. The third mega environment consisted of Ngetta 1 and Namulonge 1. Genotype GC 84051-31-1 was the best genotype; and AMMI biplot explained $55.79 \%$ of the G+GE variation.

Results for comparison biplot which was genotype focused for fresh seed yield are presented in Figure 3. The biplot shows G104227 as the ideal genotype for fresh seed yield. The other genotypes which were close to the ideal were PI606405, PI615437-B and PI628906. Genotypes AGS 329, G548360 and G8527 were the least ideal genotypes.

The results of environment focused comparison biplot are shown on Figure 4. The biplot shows that the ideal environment to be Nakabango 1, while MUARIK 1 was closer to the ideal. The worst environment for fresh seed yield was Iki Iki 2.

\section{DISCUSSION}

Plant height. Genotypes were grouped as tall, medium and dwarf showing the different natural abilities of the different genotypes in height (Table 2). Different genotypes tend to have different genetic abilities for height, which is quantitatively influenced by the environment. Most vegetable soybean varieties do not grow tall (Sharma and Kshattry, 2013), which was confirmed in this study (Table 2). The vegetable soybean height may have an impact on the final yield of the crop as was previously observed that main stem height of the vegetable soybean positively correlates with 
Plot of Gen and Env IPCA 1 scores versus means

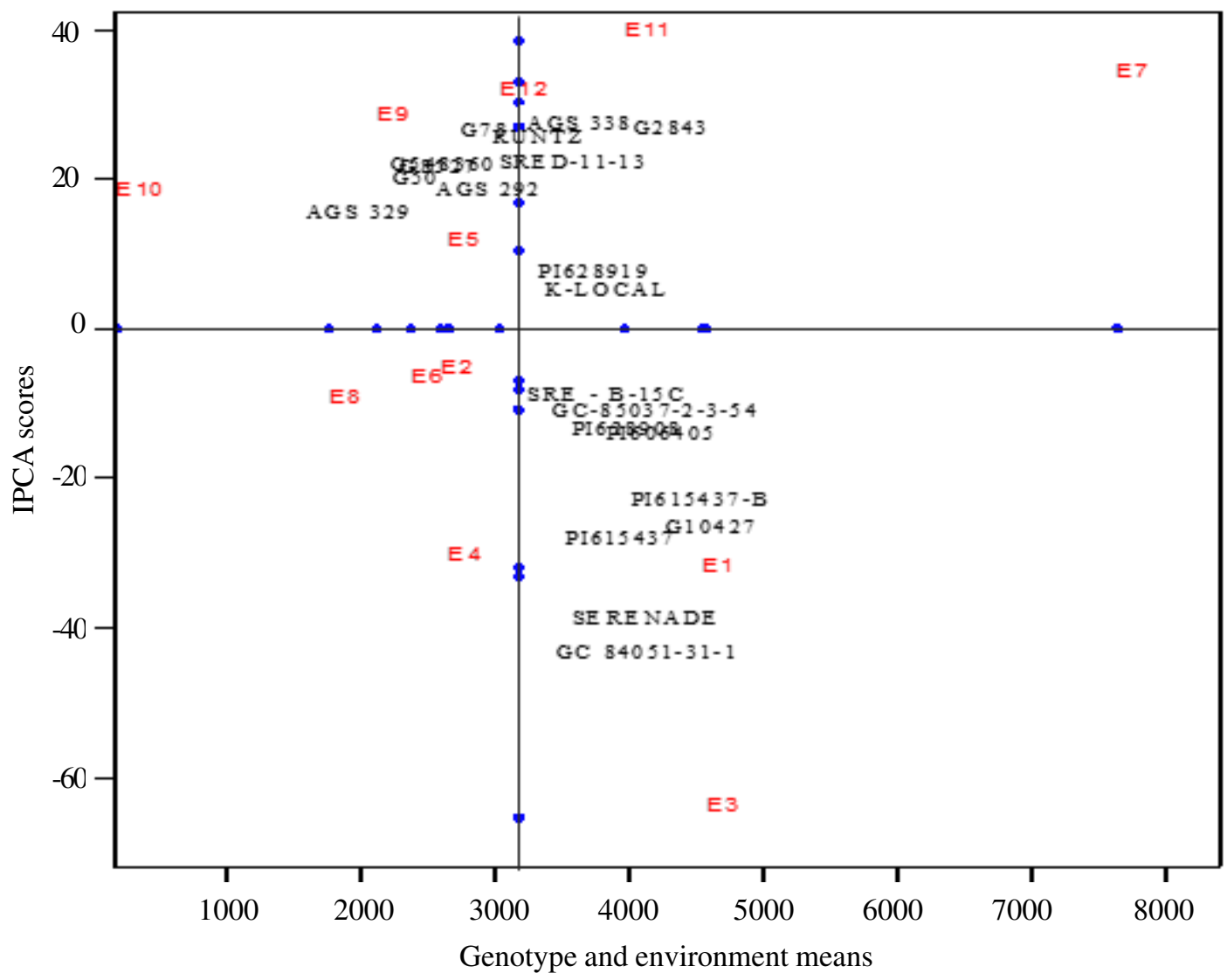

Figure 1. AMMI biplot of IPCA1 scores versus fresh seed yield means for 21 vegetable soybean genotypes evaluated in 12 environments in Uganda. E1 = MUARIK 1, E2 = Namulonge 1, E3 = Ngetta 1, E4 = Iki Iki 1, E5 = Mubuku 1, E6 = Nakabango 1,E7 = MUARIK 2, E8 = Namulonge 2, E9 = Ngetta 2, E10 = Iki Iki 2, E11 = Mubuku 2, E12 = Nakabango 2.

yield (Mebrahtu et al., 1991; Sarutayophat, 2012).

Days to $50 \%$ flowering and to maturity. The genotypes flowering period ranged from 27 to 45 days for PI628919; and maturity period ranged from 64 (AGS 329) to 106 (PI628919) days after planting (Table 2). Flowering and maturity of the genotypes could have been influenced by temperature and latitude as soybean is sensitive to both (Jiang et al., 2014; Santachiara et al., 2017). Therefore, the genotypes used in the study exhibited the early maturing growth type in Uganda as expected. However, differences in maturity days were seen among the genotypes showing the different latitudinal adaptations for the different genotypes as reported in other studies ( Salmeron et al., 2014; Weller and Ortega, 2015; Santachiara et al., 2017). In India most vegetable soybean varieties would mature around 75 days after planting (Sharma and Kshattry, 2013; Poornima et al., 2014), but other varieties matured at 124 days after planting (Zhang and Boahen, 2007) a range which corroborates well with the current study. Variations could also be seen for the same genotype from season to the next in the same year; implying interactions with the environment. It is therefore important to select 
Scatter plot (Total $-55.79 \%$ )

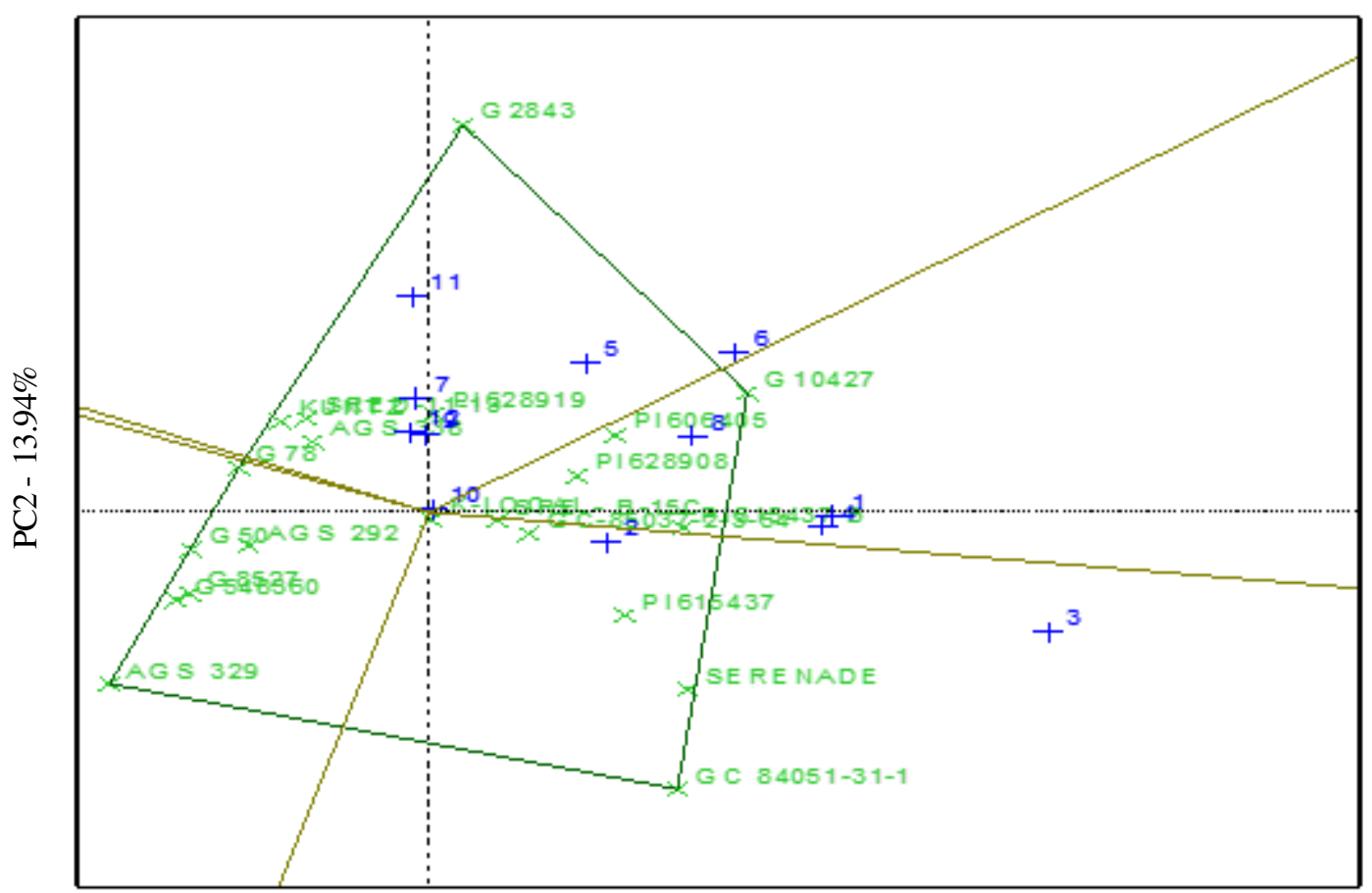

PC1 - 41.85\%

$\begin{array}{cl}\prec & \text { Genotype scores } \\ +\quad & \text { Environment scores } \\ & \text { Convex hull } \\ & \text { Sectors of convex hull }\end{array}$

Figure 2. Mega environments and vertex genotypes for fresh seed yield $\left(\mathrm{kg} \mathrm{ha}^{-1}\right)$ of the 21 vegetable soybean genotypes in Uganda.

the most appropriate season of the year in which maturity can be leveraged on, for example early maturity to allow for quick rotations. All the genotypes used in this research fell within the range expected of (75125 days) vegetable soybean at R6 stage. This concurs with what was observed in India (Sharma and Kshattry, 2013; Poornima et al., 2014) showing the genetic ability of vegetable soybean to mature early. AGS 329 had the shortest period to maturity of 64 days, a difference that was due to the high temperatures in Uganda when compared to Taiwan from which it originated.
Pod number. The vegetable soybean genotypes used in this study produced less pods per plant, with AGS 329 and GC 8405131-1 producing as low as 10 pods per plant and only 2 genotypes (PI615437-B and G8527) producing above 25 pods per plant (Table 2 ). The low pod number of most of the genotypes like for AGS 329 and GC 84051-31-1 could be due to the short height and the less branching growth habit.

There was a positive correlation between height and pod number in vegetable soybean (Sarutayophat, 2012) hence breeders may take advantage of this correlation by practicing 


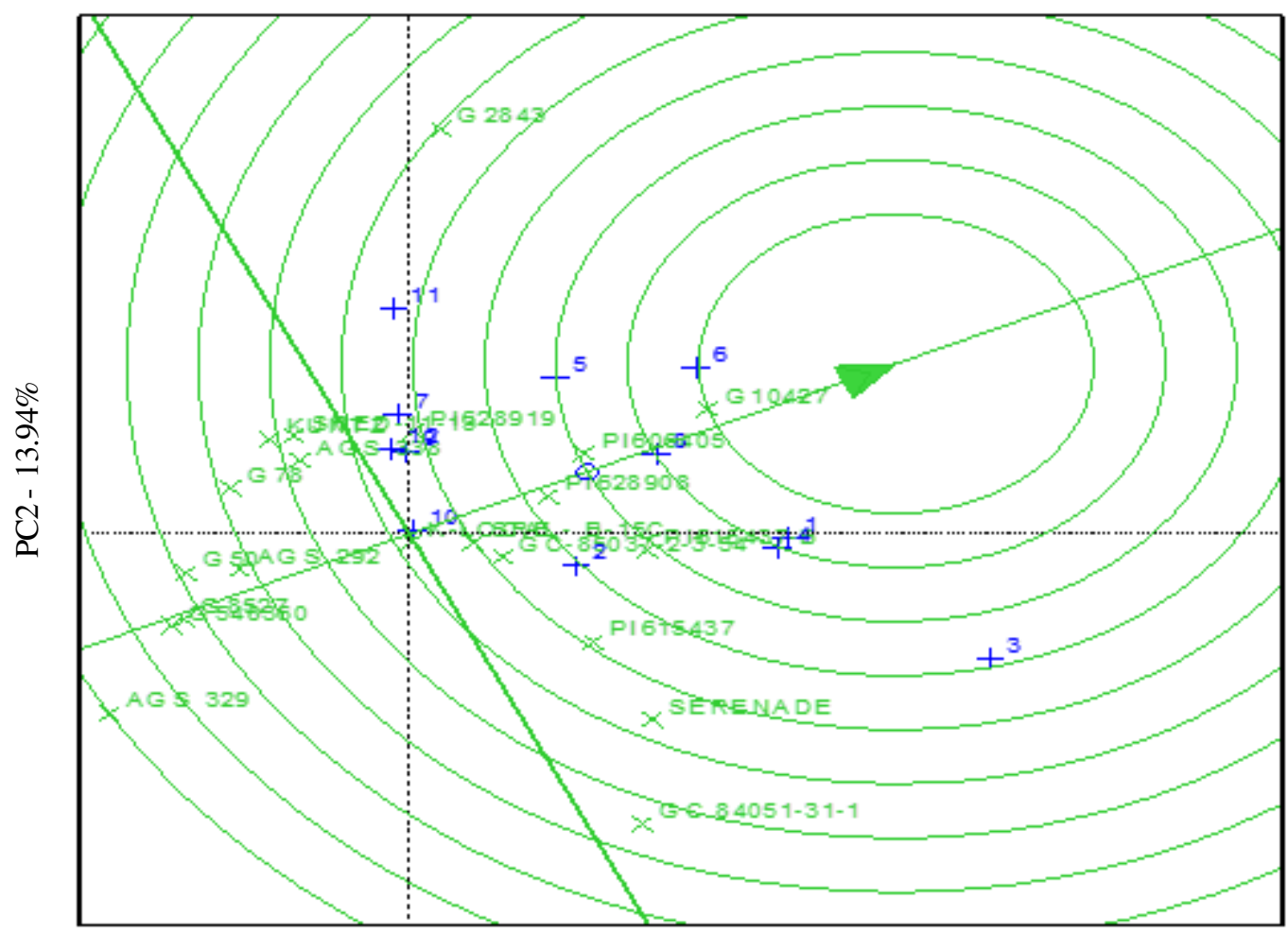

PC1 - $41.85 \%$

$$
\begin{aligned}
& \times \text { Genotype scores } \\
& + \text { Environment scores } \\
& \text { AEC }
\end{aligned}
$$

Figure 3. Genotype focused comparison biplot for fresh seed yield $\left(\mathrm{kg} \mathrm{h}^{-1} \mathrm{a}\right)$ of vegetable soybean in Uganda.

indirect selection, in which taller vegetable soybean genotypes can be selected to increase pod number.

The short height and less branching reduces the number of nodes from which pods can be formed, and thus less pods will be formed.

The number of pods produced by the AVRDC genotypes were much lower than previously reported by Poornima et al. (2014), which could rarely go below 20 pods per plant imposing a limit to final yield, thus calling for improvement of the current genotypes for more nodes to subsequently increase pod clusters.

100 seed weight and total yield. Only three genotypes, AGS 292, AGS 329 and AGS 338, managed to achieve a 100 seeds weight greater than $30 \mathrm{~g}$. The large seed size of these genotypes contributed to the high weight of 100 seeds. These genotypes from AVRDC were specifically selected and bred for large seed size, since it satisfied the market requirements which also impacted on the protein and oil content (Mentreddy et al., 
Comparison biplot (Total - 55.79\%)

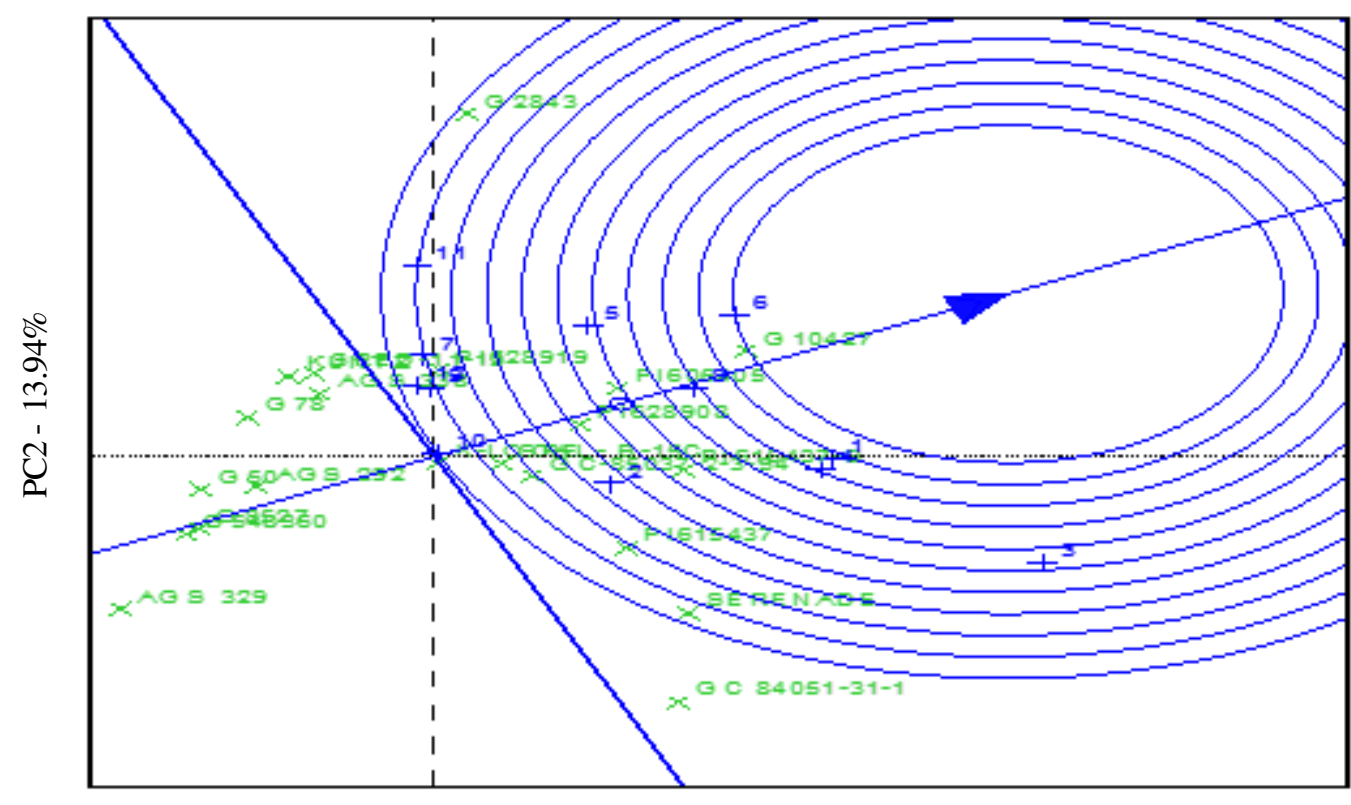

PC1 - 41.85\%

$\times$ Genotype scores

+ Environment scores

O AEC

Figure 4. Environment focused comparison biplot vegetable soybean for fresh seed yield $\left(\mathrm{kg} \mathrm{ha}^{-1}\right)$ in Uganda.

2002). Most of the USA genotypes had small seed size, thus had lower 100 seeds weight. The high temperatures in Uganda could have also hastened growth, thus reducing the time of grain filling and lowering the grain weight. From the results, it therefore means that only three genotypes could be classified as vegetable soybean as set out by Konovsky et al. (1994) that a 100-seed weight of vegetable soybean should exceed $30 \mathrm{~g}$. Meanwhile, Roseboro (2012) found out that most USA varieties are three quarters the size of the Chinese varieties which were mostly sourced from AVRDC. This is in agreement with our research findings which generally found out that AVRDC genotypes weigh more than the USA genotypes because of the seed size.
Most of the AVRDC genotypes yielded less than the USA genotypes (Table 3), although several genotypes from AVRDC had been bred to adapt to the tropics (Chadha and Oluoch, 2004). The low yields could be attributed to the short height of the genotypes attained in Uganda, since there is a positive correlation between height and yield (Sarutayophat, 2012). The short plants in Uganda led to the low number of pods per plant due to limited number of nodes from which pods could be formed resulting in low fresh seed yields. The USA originating genotypes were taller, which facilitated more buds that gave more pods resulting in a higher yield. Genotypes G10427 and G2843, which were short managed to give higher fresh seed yield because of the large size sizes. 
AMMI analysis. The AMMI analysis of variance for fresh seed yield showed that the environment explained a large percentage of the treatment total sum of squares indicating that the environments were diverse (Table 4). This might be due to differences in rainfall, which is known to impact on vegetable soybean yield (Mebrahtu et al., 1991). This ability of the environment to mask the genetic potential of different genotypes has an effect on selection and testing of vegetable soybean (Mebrahtu et al., 1991). Gauch and Zobel (1996) reported that in standard multi environmental trials (METs), the greater proportion of the treatment sum of square should be contributed by the environment, which is consistent with the study findings (Table 4). A significant GxE interaction for vegetable soybean fresh seed yield is an indication of different performance of genotypes across environments and this necessitates the investigation of the nature of different responses of the genotypes to the 12 environments.

GGE Biplots for mega-environments. The three mega environments with different winning genotypes that were identified; (i) mega environment with Iki Iki 2, MUARIK 2, Ngetta 2, Mubuku 1, Mubuku 2, Nakabango 1; and Nakabango 2; (ii) with MUARIK 1, Iki Iki 1 and Namulonge 2, and (iii) with Ngetta 1 and Namulonge 1. This implies that when focusing on fresh yield in vegetable soybean, the country could be divided into three broad regions with unique characteristics for specific high yielding genotypes (Fig. 2). The winning genotypes in the different mega environments could be recommended for these areas for production. Genotype G2843 could be recommended for the environments Iki Iki 1, MUARIK 1, Ngetta 2, Mubuku1, Mubuku 2, Nakabango 1 and Nakabango 2 (the first mega environment); while G10427 can be recommended for Iki Iki 1, MUARIK 1 and Namulonge 2. GC84051-31-1 could be recommended for the third mega environment which comprised of Ngetta 1 and Namulonge 1.

Genotype focused comparison biplots revealed that G10427 was the ideal genotype across all the environments. A genotype is more desirable if it is located closer to "ideal" genotype (Kaya et al., 2006). This means that G10427 was stable and was able to maintain a sustainable yield across all the environments since it performed averagely well in the diverse environments. However, a fresh seed yield of $4281 \mathrm{~kg} \mathrm{ha}^{-1}$ attained by G10427 was relatively lower compared to fresh seed yield attained elsewhere (Sharma and Kshattry, 2013; Poornima et al., 2014) . For example, in Georgia, genotypes had fresh seed yield ranging from 7300 to $11600 \mathrm{~kg} \mathrm{ha}^{-1}$. Therefore, breeding for higher yields in Uganda may be pursued for future research.

The environment based comparison biplot showed that Nakabango 1 was ideal for fresh seed yield (Fig. 4). Nakabango received the highest rainfall compared to the other locations, during the first season, which could have created a suitable growing environment to be able to discriminate among the vegetable soybean genotypes more than the other environments. Iki Iki 2 was the least suitable environment, possibly due to the mid-season drought experienced during the season. Iki Iki is also characterised by poor sandy soils with low water retention capacity, which could have impacted on the performance of the different genotypes when there was moisture shortage (Tukamuhabwa et al., 2012).

\section{CONCLUSION}

From this study, vegetable soybean genotype G10427 is the most adapted and stable genotype among the discriminating environments of Uganda agro-ecological zones, producing a mean of $4281 \mathrm{~kg} \mathrm{ha}^{-1}$. Based on this study, Uganda can be divided into three mega environments for vegetable soybean fresh seed yield; with Nakabango 1 and MUARIK1 being the most discriminating 
environments; thus, they can be used as test environments for improvement of vegetable soybean yield in Uganda. It is recommended that $\mathrm{G} 10427$ be used as a test genotype, which can be improved to produce a variety with good attributes, especially large seed, high yield and adaptable to Uganda.

\section{ACKNOWLEDGEMENT}

We would like acknowledge Intra ACP STREAM for providing financial support for the research and the Makerere University Soybean Breeding Programme for hosting the research.

\section{REFERENCES}

Bolla, K.N. 2015. Soybean Consumption And Health Benefits. International Journal of Scientific and Technology Research 4(7): 50-53.

Burker, R.J. 2001. Edamame soybeans from Vancouver to Kampala. In T. . Lumpkin and S. Shanmugasundaram, eds. Second International Vegetable Soybean Conference. Washington, USA: Pullman: 27-28.

Chadha, M.L. and Oluoch, M.O. 2004. Vegetable soybean research and Dvpt in Africa. In: $7^{\text {th }}$ World Soybean Research Conference, Londrina: Brazilian Agricultural Research Corporation, National Soybean Research Center. pp. 921-928.

Duppong, L.M. and Hatterman-Valenti, H. 2005. Yield and quality of vegetable soybean cultivars for production in North Dakota. Horticulture Technology, 15(4): 896-900.

Gauch, H.. and Zobel, R. 1996. AMMI analysis of yield trials. In M. S. Kang \& H. . Gauch, eds. Genotype by environment interaction. New York, USA: Boca Raton CRC: 85122 pp.

Hartman, G.L., West, E.D. and Herman, T.K. 2011. Crops that feed the World 2. Soybean-worldwide production, use, and constraints caused by pathogens and pests. Food Security 3(1): 5-17.
Jiang, B., Nan, H., Gao, Y., Tang, L., Yue, Y., Lu, S., Ma, L., Cao, D., Sun, S., Wang, J., Wu, C., Yuan, X., Hou, W., Kong, F., Han, T., and Liu, B. 2014. Allelic combinations of soybean maturity loci E1, $\mathrm{E} 2, \mathrm{E} 3$ and E4 result in diversity of maturity and adaptation to different latitudes. PLoS ONE 9(8): 1-11

Kokobun, M., 1991. Cultural practices and cropping systems for vegetable soyben in Japan, AVRDC, Taiwan. 151pp

Konovsky, J., Lumpkin, T.A. and Mcclary, D. 1994. Edamame/: The vegetable soybean. In A. D. O'Rourke, ed. Understanding the Japanese food and agrimarket: A multifaceted opportunity. Binghamton: Haworth Press. 181pp.

Mebrahtu, T. and Devine, T.E. 2009. Diallel analysis of sugar content of 10 vegetable soybean lines. Plant Breeding 128: 249252.

Mebrahtu, T., Mohamed, A. and Mersie, W. 1991. Green Pod Yield and Architectural Traits of Selected Vegetable Soybean Genotypes. Journal for Production Agriculture 4(3): 395-399.

Mentreddy, S. R., Mohamed, A.I., Joshee, N. and Yadav, A.K. 2002. Edamame/ : A nutritious vegetable Crop. In: Janick, J. and Whipkey, A. (Eds.). Trends in wew crops and new uses. Alexaandra, VA: ASHS Press. 438pp

Mohamed, M. 2013. Genotype by environment interactions for grain yield in bread wheat (Triticum aestivum L.). Journal of Plant Breeding and Crop Science 5(7): 150-157.

Mustapha, M. and Bakari, H.R. 2014. Statistical evaluation of genotype by environment interactions for grain yield in millet (Penniisetum glaucum ( L.) R.Br). The International Journal of Engineering and Science 3(9):7-16.

Poornima, R., Koti, R. V. and Nair, M.R. 2014. Physiological basis of yield variation in vegetable soybean and organoleptic test for acceptance. Plant Archives 14(1):51-54.

Roseboro, K. 2012. Edamame offers good non-GMO opportunities to US farmers. $\mathrm{p}$. 
3. [Online]. Available at: http://www.nongmoreport.com/articles/april2012/ edamame-non-gmo-us-farmers.php Accessed 1 December 2014.

Sakai, T. and Kogiso, M. 2008. Soy isoflavones and immunity. The Journal of Medical Investigation 55(3-4):167-73.

Salmeron, M., Gbur, E. E., Bourland, F. M., Buehring, N. W., Earnest, L., Fritschi, F. B., Golden, B. R., Hathcoat, D., Lofton, J., Miller, T. D., Neely, C., Shannon, G., Udeigwe, T. K., Verbree, D. A., Vories, E. D. Wiebold, W. J. and Purcell, L. C. 1. 2014. Soybean maturity group choices for early and late plantings in the midsouth. Agronomy Journal 106(5):1893-1901.

Santachiara, G., Borrás, L. and Rotundo, J.L. 2017. Physiological processes leading to similar yield in contrasting soybean maturity groups. Agronomy Journal 109(1):158167.

Sarutayophat, T. 2012. Correlation and path co-efficient analysis for yield and its components in vegetable soybean. Songklanakarin Journal of Science and Technology 34(3):273-277.

Shanmugasundaram, S. and Yan, M.R. 2004. Global expansion of high value vegetable soybean. Vii World Soybean Research Conference - VI International Soybean Processing and Utilization Conference - iii Congresso Brasileiro De Soja, Proceedings. pp. 915-920.

Sharma, K.P. and Kshattry, I. 2013. Varietal adaptation study to initiate edamame production in Richmond, BC. Nature's Path foods. Richmond BC. 29pp.

Shurtleff, W. and Aoyagi, A. 2009. History of edamame, green vegetable soybeans, and vegetable-type soybeans (1275 - 2009): extensively annotated bibliography and sourcebook, Soyinfo Center, Lafayette, USA. 764pp.
Singh, R. K., Bhatia, V. S., Yadav, S., Athale, R., Lakshmi, N., Guruprasad, K. N., and Chauhan, G. S. 2008. Identification of genetically diverse genotypes for photoperiod insensitivity in soybean using RAPD markers. Physiology and Molecular Biology of Plants 14(4):369-375.

Srisombun, S., Ratanarat, S., Kaewmeechai, S. and Shanmugasundaram, S. 2004. Vegetable soybean research and development in Thailand. In: Moscardi, M., Hoffmann Campo, F., Saraiva, C., Calerani, O., Krzyanowski, P. and CarraoPanizzi, F. (Eds.). 7th World Soybean Research Conference. Londrina: Brazilian Agricultural Research Corporation, National Soybean Research Center. pp. 929-935.

Tsubokura, Y., Matsumura, H., Xu, M., Liu, B., Nakashima, H., Anai, T., Kong, F., Yuan, X., Kanamori, H., Katayose, Y., Takahashi, R., Harada, K., and Abe, J. 2013. Genetic variation in soybean at the maturity locus E4 is involved in adaptation to long days at High Latitudes. Agronomy 3(1):117-134.

Tukamuhabwa, P. and Oloka, H. 2016. Soybean research and development in Uganda: A case of paradigm shift in an African Universities (2002-2015), Kampala, Uganda: Makerere, University. A report publication consolidating advances in soybean research in Uganda

Watanabe, S., Harada, K. and Abe, J. 2012. Genetic and molecular bases of photoperiod responses of flowering in soybean. Breeding Science 61(5): 531-543.

Weller, J.L. and Ortega, R. 2015. Genetic control of flowering time in legumes. Frontiers in Plant Science 6(207):1-13.

Zhang, L. and Boahen, K.S. 2007. Growth and yield of vegetable soybean (Edamame) in Mississippi. Horticulture Technology 17(1):26-31. 